\title{
Tulsi - A Review Based Upon Its Ayurvedic and Modern Therapeutic Uses
}

\author{
Shifali Thakur ${ }^{1}$, Shailja Choudhary ${ }^{2}$, Bhawna Walia ${ }^{3}$, Gitika Chaudhary $^{4}$ \\ ${ }^{1,2,3,4}$ Shuddhi Ayurveda, Jeena Sikho Lifecare Pvt. Ltd. Zirakpur 140603, Punjab, India. \\ Corresponding Author: Gitika Chaudhary
}

\begin{abstract}
Herbal plants are considered as the most significant source of medicines. These herbal plants are in practice from ancient times. Traditionally, all the parts of the plant are used for curing various diseases. One of the most important herbal plants is the Ocimum sanctum also called tulsi. This plant is considered a sacred plant in Indian culture and used for holy purposes as well. The name Tulsi comes from Sanskrit word which means "the incomparable one". Tulsi plant is not only used in ayurvedic medicines but also used in other medicinal systems in Greek, Roman and Unani. Apart from this, the Tulsi plant possesses different therapeutical properties due to the presence of several phytochemical constituents in its roots, stem, fruit, and leaves due to the presence of eugenol, vallinin, gallic acid, palmitic acid, oleic acid, linoleic acid, and many more. These phytochemicals are extracted from the plant and used to cure various types of diseases. Tulsi is reported to have properties like anti-ulcer, antioxidant, anti-inflammatory, anti-cancer, antidiabetic, anti-arthritic, analgesic, antistress, anti-asthmatic, antifertility, immunomodulatory, and neuroprotective activity.
\end{abstract}

Keywords: Ocimum sanctum, phytochemicals, Eugenol, Tulsi, Ayurveda

\section{INTRODUCTION}

Plants are known for various medicinal properties from ancient times. The essential oils extracted from therapeutic plants are safe, economical, effective and easily available ${ }^{[1,2,3,4]}$. India is the home for more than 8000 species of vascular plant out of which 1748 are considered for their therapeutical uses ${ }^{[5]}$. Tulsi (Ocimum sanctum $L$ ) is one of the most common herb used in Indian traditional system and also named as "Holy Basil", "Queen of Herbs" [6,7]. The name Tulsi comes from Sanskrit word that means "the incomparable one" [8]. In Indian culture, it is worshiped very religiously and known as "Vishnupriya". The scientific name of Tulsi is Ocimum sanctum (Linn) which belongs to the Labiatae family and the Ocimum genus is derived from the Greek word ozo which means to smell or having strong odor [9]. This plant has about 160 species in which Ocimum sanctum, Ocimum gratissimum, Ocimum canum, Ocimum basilicum, Ocimum killimandscharicum, Ocimum ameicanum, Ocimum camphora and Ocimum miranthum are therapeutically important ${ }^{[10,11] .}$ There are commonly three types of Tulsi that are considered the most i.e. Ocimum tenuiflorum (Krishna tulsi), Ocimum sanctum (Rama Tulsi) and Ocimum gratissimum (Vana Tulsi) [12]. Numerous phytochemical constituents isolated from this plant which are responsible for their medicinal value both in modern medication system and traditional medication system i.e. Ayurveda, Unani, Siddha, Greek and Roman ${ }^{[13] . ~ T h e ~ p r e s e n c e ~ o f ~ p h y t o c h e m i c a l s ~}$ may vary in this plant because of its cultivation and harvesting procedure. In Ayurveda, it is explained as "the elixir of life" and believed to promote longevity. Our review is focused on a detailed description of Tulsi (Ocimum L) and its medicinal significance as per different medicinal 
systems. Botanical Classification and vernacular names of Ocimum sanctum is given below in table no. $1^{[14]}$ and table no. 2 [15].

Table 1: Botanical Classification of Ocimum sanctum

\begin{tabular}{|l|l|}
\hline Taxonomic Rank & Taxon \\
\hline Kingdom & Plantae \\
\hline Division & Magnoliophyta \\
\hline Class & Magnoliopsida \\
\hline Order & Lamiales \\
\hline Family & Lamiaceae \\
\hline Genus & Ocimum \\
\hline Species & Ocimum sanctum \\
\hline
\end{tabular}

Table 2: Vernacular names of Ocimum sanctum

\begin{tabular}{|l|l|}
\hline Vernacular Names & Basilie, Sweet Basil \\
\hline English & Besil, Tulsi, Jangli tulsi \\
\hline Hindi & Loh lahk, Yu heung choi \\
\hline Chinese & Dohsh, Schadjant, Vasub \\
\hline Middle East, North Africa & Shahasbram, Rehan \\
\hline Armenia & Bosilek \\
\hline Bulgaria & Laun, Pinzainpinzin \\
\hline Burma & Basilikum \\
\hline Denmark, Greenland & Baziel, Koningskruid \\
\hline Netherlands, South Africa & Basilie, Sweet Basil \\
\hline England & Basilika \\
\hline Finland, Sweden, Norway & Basilic sacre, Herbe royale \\
\hline France & Rekhani, Rehan \\
\hline Georgia & Indisches Basilikum \\
\hline Germany & Basilika \\
\hline Iceland & Basilico \\
\hline Italy & Bajiru, Kami-meboki \\
\hline Japan & Che tak, Mareah proeu \\
\hline Cambodia & Naruk-pul, Yanggajuk \\
\hline Korea & Saphaa, Phak i tou thai \\
\hline Northeast of Thailand & Kemangi, Selasi jantan \\
\hline Malaya & Tulsi patta, Bavari phul \\
\hline Nepal & Madurutala, Mudura tulla \\
\hline Sri Lanka & Alfabega, Albacar \\
\hline Spain & Basilika, Basilkaort \\
\hline Swedish & Nhu tia, Cay hung que \\
\hline Vietnam & Tuloxi, Tulasii \\
\hline Assam, North-East India & Tulsi, Kalotulsi, Kural \\
\hline West Bengal & Tulsi, Niyan Posh \\
\hline Himachal Pradesh & Sabje, Talasi \\
\hline Gujarat & Karitulasi,, Tulasiya \\
\hline Karnataka & Pachcha, Kunnakam \\
\hline Kerala & Mayangton, Naoshek lei \\
\hline North-eastern India & Sabja, Tulasa \\
\hline Maharashtra & Dhala tulasi, Karpura \\
\hline Orissa & Tulsi \\
\hline Punjab & Oddhi, Rudrajada \\
\hline Tamilnadu & \\
\hline Andhra Pradesh & \\
\hline Kashmir, North India & \\
\hline & \\
\hline &
\end{tabular}

\section{Botanical Description}

Ocimum sanctum belongs to the family Lamiaceae/Labiate. Tulsi is an erect, branched, fragrant plant with height reaches upto $30-60 \mathrm{~cm}$ when completely mature. The leaves of Tulsi are simple, inverse, elliptical, ovoid, dense or acute with entire margin. The leaves grow up to $5 \mathrm{~cm}$ long. It has small phyllotaxy and petiole is $2-5 \mathrm{~cm}$ long, slender and pubescent. The leaves of the plant mainly possess medicinal property. They are also pubescent on both sides with small glands. The stomata are present on the lower surface but also rarely present on the upper surface of leaf. The flowers of this plant consist of verticillaster inflorescence with varying color from purple to pink. Flowers are simple or branched raceme 5$30 \mathrm{~cm}$ of height, bracts sessile, ovate, caduceus, hermaphrodite, pedicel 1-4 mm long, spreading or slightly curved. Flowering started after 136 days and continue up to 195 days and their seeds matures after 259 days. Fruit having 4-dry, 1 - seeded nut lets covered in the persistent calyx; long up to $1.5 \mathrm{~mm}$, rugose brown, outer pericarp does not turn into mucilaginous in water. It produces small seeds which are reddish black in colour. Stem are green in newly born plant and become woody when getting older. The roots of the Ocimum sanctum contains various essential oil like eugenol ${ }^{[16,17,18,19] \text {. }}$ Plant is shown in figure 1.

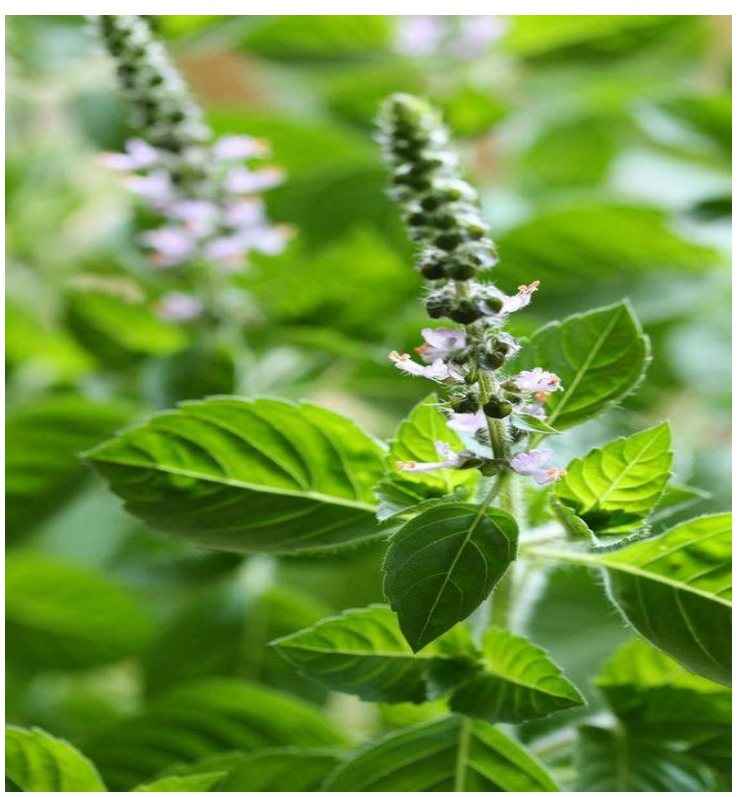

Figure 1. Tulsi (Ocimum sanctum)

\section{Geographical Distribution}

$O$. sanctum is extensively distributed in tropical and subtropical parts of Asia. The plant is indigenous to the Indian subcontinent including the Himalayas, Malaysia, Caribbean, Pacific and other parts 
of Africa. In India it is cultivated in almost every state ${ }^{[20] .}$ Due to some holy believes it is present around the temples and places of worship. Till now there is no data available regarding specific habitats where the species has been found naturally ${ }^{[21,22]}$.

\section{Phytochemical constituents of Ocimum sanctum}

The leaves of Ocimum sanctum reported to be a rich source of volatile oil containing eugenol $(71 \%)$ and methyl eugenol $(20 \%)$ content. The volatile oil also consists of carvacrol and sesquiterpine hydrocarbon caryophyllene. The other chemical constituents present are phenolics, flavonoids, terpenoids and fatty acids. The seeds of plant are enriched with fixed oil (18-22\%), polysaccharides mucilage and $\beta$ sitosterol. Linoleic acid is considered as the main content present in seed oil [23]. The other chemical constitutes present are:

1. Phenolics: The phenolic content found in OS plant consist of chlorogenic acid, vanillic acid, ocimumnaphthanoic acid, caffeic acid and menthylsalicylic glucoside that are extracted from the aerial parts of the plant ${ }^{[24]}$. The other chemical constituents present was confirmed by HPLC which comprises of gallic acid ethyl ester, protocatechuic acid, 4-hydroxynbenzoic acid, gallic acid methyl ester, vanillin and 4hydroxybenzaldehyde ${ }^{[25,26] \text {. }}$

2. Flavonoids: Flavonoids are considered as the main constituents which consist of methoxy flavonoids and their glycosides (cirsimartin, isothymusin, luteolin), Cglycosides flavonoids (vicenin, isovitexin, isoorientin and orientin) of the OS plant [27]. The other flavones detected using atmospheric pressure chemical ionization mass spectrometry (APCI-MS) are cirsumaritin, crisilineol, isothymusin, gardenin, apigenin, eupatorin and salvigenin ${ }^{[28] .}$

3. Phenyl propanoids Eugenol is the main component found in the essential oil of OS leaves. The other phenyl propanoids derivatives are ociglycoside or $\quad$ eugenyl- $\quad \beta$-D-glucoside, ferualdehyde, citrusin $C$ and dehydrodieugenol were extracted from the leaf part of the OS plant ${ }^{[29] .}$

4. Neolignans: The methanolic extracts of OS plant possess to have neolignans constituents consist of Tulsinol A to Tulsinol $G$ which are formed by polymerization of eugenol content ${ }^{[29] \text {. }}$

5. Terpenoids: The terpenoids reported in OS plant are sesquiterpenoids $(\beta-$ caryophyllene and 4,5- epoxycaryophyllene), abietane diterpenoid (carnosic acid), ursane triterpenoids(

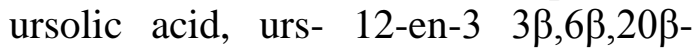
triol-28-oic acid and oleane triterpenoids (oleanic acid, $\quad \beta$-Amyringlucopyranoside) ${ }^{[8]}$. The most abundant constituent found by HPTLC and UPLC-ESI-MS/MS is ursolic acid [30]. Other terpenoids constituents isolated were $\beta$-caryophyllene, elemene, $\alpha$ humulene, $\alpha$-caryophyllene, germacrene, trans- $-\alpha$-bergamotene and $5 \beta$ hydroxycaryophyllene ${ }^{[31] \text {. }}$

6. Coumarins: There are three coumarins constituents extracted from tulsi plant named aeculetin, aesculin and ocimarin [32].

7. Steroids: he steroid components present are $\beta$-sitosterol, $\beta$-sitosterol-3-O $\beta$-Dglucopyranoside, stigmasterol and campesterol which are extracted from the stem and leaves of OS ${ }^{[33]}$

8. Essential oil: The essential oil extracted from leaves of OS plant is mainly composed of terpenoids which include phenolic acid, esters, aliphatic aldehydes, bicyclic terpenoids, acyclic monoterpenoids and sesquiterpenoids. The chemical composition varies from region to region depend upon its cutivation, harvesting, climatic 
conditions. The major phytochemicals present in essential oil are eugenol or methyl eugenol and methyl chavicol which is responsible for the antimicrobial and anthelmintic property [34]. The other constituents present in essential oil are, $\beta$-caryophyllene, $\beta$ caryophyllene oxide and germacrene D [35].

9. Fixed oil (non-volatile oil): The fixed oil isolated from OS seeds constitute $18.22 \%$ which is mainly composed of linoleic acid $(66.1 \%)$, which possess anti-inflammatory, hypotensive, chemopreventive anticoagulant properties [36]. The other constituents present are stearic acid (2.1\%), oleic acid (9.0\%), palmitic acid (6.94\%) and, $\alpha$-linolenic acid (15.7\%) which are extracted from the leaves of OS leaves [37].

10. Fatty acid derivatives: The fatty acid derivatives extracted from the roots and leaves of the OS plant are cerebrosides. Also, palmityl glucoside and sanctumoic acid present in OS leaves are responsible for mosquitocidal property ${ }^{[38] .}$

\section{Traditional and Modern View on plant} A. Folk View of Tulsi (Ocimum sanctum)

Tulsi (Ocimum sanctum) is considered a medicinal plant from ancient times. The literature indicates that the medicinal use of plants is as old as 4000$5000 \mathrm{BC}$. The natural herbal preparation of medicines was firstly done by the Chinese. In India, the Tulsi plant was formulated into medicine between 3500-1600 BC. Later the therapeutic uses were studied and recorded empirically by the ancient physicians ${ }^{[39]}$.

The plant is a part of religious belief around the world, especially in India. Although there is no literature available on basil in the Bible ${ }^{[40],}$ the plant is said to have grown at the site of Christ's crucifixion [41]. It is mainly sanctified in Hindu Folklore. The plant is known to be the manifestation of the goddess, Tulsi was raised from her embers. There are many stories regarding the Tulsi, but the well-known comes from Shiva Purana. Once Indra and Bri haspati went to meet lord Shiva at the Kailash mountain and their way was blocked by a sage. The sage was Shiva himself. Lord Shiva transforms his look with tangled hair and a resplendent face just to test Indra and Bri haspati. Indra did not recognize the lord Shiva and got furious that the man was not moving out their way. To move him out of his way Indra threatened him with his thunderbolt. Lord Shiva became infuriated upon this deed and got angry. Due to his anger, his third eye got opened to kill Indra but at the same, the Bri haspati recognized lord Shiva. He requested Shiva to pardon Indra. Lord Shiva was convinced by Bri haspati and propelled the fire from his eye towards the ocean. The collision of fire and ocean took the form of a boy who was named Jalandhara. Jalandhara grew up powerful and become a king of demons by Guru Sukra. He got married to Vrinda, who was the daughter of demon Kalanemi. Bhrugu made him against Lord Vishnu as well as other gods. A battle occurred between Jalandhara and Vishnu which reminded inconclusively. Influenced by the bravery of Jalandhara, Vishnu asked him in ksira sagara and as accepted by lord Vishnu, in the absence of all gods got defeated by Jalandhara. Devas did not want to be governed by Jalandhara. The Devas consulted with sage Narada to meet Jalandhara. But he illustrated the beauty of Kailasa in his visit. Sage Narada then continued to describe Shiva's residence and the beauty of goddess Parvati ${ }^{[42] .}$ Listening to this Jalandhara disguised himself as Shiva and went to Parvati just to trick her. Parvati identified him and endeavored to strike him but Jalandhar ran away. After this Parvati went to Lord Vishnu and requested him to trick Vrinda just like Jalandhar does. Vrinda was very virtuous to Lord Vishnu for the restoration of Jalandhara's destruction by Shiva. Hearing this, Vrinda embraced Jalandhara who is Vishnu in reality. When Vrinda realized the fact she cursed Lord 
Vishnu that somebody would seize his wife (which was later done in Ramayana) and also become the stone. Just honoring his real devotee, he accepted the curse and appears as the stone named Saligrama sila in the Gandika river in Nepal. In the end, Vrinda stepped into the fire to immolate herself. When Jalandhara came to know about his wife's death, he became angry and turn into a battlefield. Hence Jalandhara was killed by Lord Shiva. Hid soul merged with Shiva just like Vrinda's soul had merged with Parvati. Vrinda is as late named as Tulsi because of her faithfulness and her denotion towards lord Vishnu. In her suffering, Tulsi ended up her life and Lord Vishnu affirmed that she would be "worshipped by women for her faithfulness" [43,44]. Thus in Hinduism, it may be considered as the symbol of love, eternal life, purification, and protection. Also, it is used in burial ceremonies for purification ${ }^{[45] \text {. }}$

\section{B. Ayurvedic View on Tulsi (Ocimum sanctum)}

Tulsi is also called "the elixir of life" because it promotes longevity. Every part of the plant. It possesses some therapeutic property and is also used in the Ayurveda and Siddha systems of medicines. Tulsi is considered as the earliest herbs known to humanity, which act as a medicine for the prevention and cure of many diseases mainly common cold, headache, cough, flu, earache, fever, colic pain, sore throat, asthma, hepatic diseases, malaria fever, wound insomnia, arthritis, digestive disorder, night blindness and influenza. The intake of the leaves of Tulsi recover lesions and act as memory enhancer ${ }^{[46,47]}$. Rasa panchak of Tulsi is given in Table No. $3^{[48] \text {. }}$

Table 3: Rasa Panchak of Tulsi (Ocimum sanctum)

\begin{tabular}{|l|l|}
\hline Sanskrit/English & Sanskrit/English \\
\hline Virya/Potency & Katu/Astrigent \\
\hline Vipak/Metabolic property & Katu,Tikt/Astringent,bitter \\
\hline Guna/Physical property & Laghu,Ruksha/Light,Dry \\
\hline Rasa/Taste & Tikt,Katu/Bitter,Astrigent \\
\hline
\end{tabular}

Action (Karma) of Tulsi: Doshas are the mind-body type and there are 3 main doshas Vata, Pitta, and Kapha, each of which is derived from the five elements. In Ayurveda "Doshas" shows the activity of physical, emotional and mental characteristics. According to Ayurveda, the medicine works on the dynamic state to maintain balance between body, mind and environment. Tulsi reduces Kapha (Water and earth component) and Vata (Air component) Dosha (disorder) and increases Pitta (Fire and water component) ${ }^{[49]}$

\section{Properties of Tulsi (Ocimum sanctum) ${ }^{[50]}$}

Abhiyantar Pachansansthan (अभ्यंतर पाचनसंस्थान): It works on the GIT, Dipana (appetizer), Pachana (digestive), Jwaraghna (antipyretic), Krimighna (wormicidal) and also kills the parasites.

Satambhikaran (सतम्भीकरण): Used for the treatment of chronic fever

\section{Dashemani Shwasaharni (दशमनी शवसहरनी): Used as an anti-asthmatic medicine.}

Sondrayavardhak (सोंदर्य वर्धक) It enhance beauty and also used in beauty products.

Raktavah Sansthan (रकत वाह संस्थान): It increases the blood circulation and Raktashodhak (Blood purifier).

Taapkaram (तापक्रम): Used for the treatment of malaria and severe fever.

\section{Modern View}

The use of Herbal medicines is in practice since ancient times. People prefer herbal medicines over allopathic medicines due to their fewer side effects and are considered as safest medicines as compared to allopathic medicines ${ }^{[51,52] .}$ To meet the demand of people, adulteration rises in the herbal drug industry which ultimately affects the health of people. The major drawback of allopathic medicines is that it generally works on suppressing the symptoms of the disease while Ayurveda medicines work on holistic approach. The holy plant Tulsi (Ocimum sanctum) contains various therapeutic properties and is used in various Ayurveda products which are available in the market to treat various 
diseases and also used in cosmetics preparation.

\section{Reported Therapeutic Uses of Ocimum sanctum}

There are several reports on the use of natural materials sources like plants, bacteria, fungi, yeast and honey. Ocimum sanctum is also considered as a wide source for the modern or herbal formulation. Various studies (like in-vivo, in-vitro) have been done for the therapeutical uses of Tulsi. Those reported studies are shown below:

1. Analgesic: It was reported that the oil extracted from Ocimum sanctum plant possesses analgesic activity. This study was carried out in mice using acetic acid-induced writhing methods, tail flick, tail clip and tail immersion. From the results, it was clear that the inhibitory activity of the oil is due to the combined inhibitory effect of acetylcholine, histamine and prostaglandin ${ }^{[53]}$.

2. Anti-oxidant: The experimental study on streptozocin-induced diabetic rats showed the antioxidant activity of $\mathrm{O}$. sanctum. It was reported that the leaves of this plant contain hydroalcoholic extract which is responsible for the antioxidant property. When the leaves of $\mathrm{O}$. sanctum were provided with streptozocin-induced diabetic rats for 30 days, it was found to improve the activity of antioxidant enzyme catalase and reduce the plasma level of thiobarbituric acid in the vital organs like kidneys and liver ${ }^{[54]}$.

3. Anti-ulcer: It was reported that the $O$. sanctum plant possesses to have antiulcer activity against histamine, aspirin, reserpine, serotonin aspirin

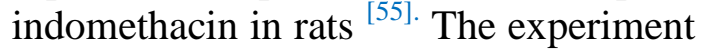
was performed in Wistar rats where it was found that the aqueous extract of $o$. sanctum protects against ethanolinduced gastric ulceration ${ }^{[56] \text {. }}$

4. Anti-arthritic: In order to find out the anti-arthritic activity, the experiment was conducted in a mice model where it was found that the oil extracted from the seeds of o. sanctum possesses antiarthritic activity against turpentine oilinduced joint pain ${ }^{[57]}$

5. Anti-pyretic activity: The fixed oil of OS was tested against typhoidparatyphoid A/B vaccine-induced pyrexia in rats and it was found that the oil extracted from the plant exhibit antipyretic activity.

6. Antitussive: It was reported that the aqueous and methanolic extracts of the OS plant showed antitussive activity when studied in guinea pigs ${ }^{[58]}$.

7. Hepatoprotective: It was reported that the leaf extract of the O. sanctum plant possesses significant hepatoprotective activity when studied against paracetamol-induced liver damage against albino rats ${ }^{[59] .}$

8. Anti-stress: It was reported that the leaves of $O$. sanctum possess antistress activity when studied in rabbits ${ }^{[60]}$

9. Anti-plasmodial: It was studied that the root and leaf extract of $O$. sanctum showed antiplasmodial activity because of the presence of ethanolic extract mainly flavonoids, phenols, saponins, alkaloids, glycosides proteins, resins, steroids, triterpenenoids ${ }^{[61] .}$

10. Memory Enhancer: To study the antidementia and anticholinesterase activity, the aqueous and alcoholic extract of the leaves of $O$. sanctum were studied in rats. Atropine, cyclosporine, and electroshock were used to activate dementia. It was reported that the inactive restraint was used to assess memory ${ }^{[62]}$.

11. Immunomodulatory: It was studied that leaves of $O$. sanctum increase the RBCs, WBCs hemoglobin and antibodies production without affecting other biochemical activities when tested in mice ${ }^{[63] \text {. }}$

12. Chemopreventive: It was reported from various studies that the oil extracted from seeds of $O$. sanctum showed chemopreventive activity against 


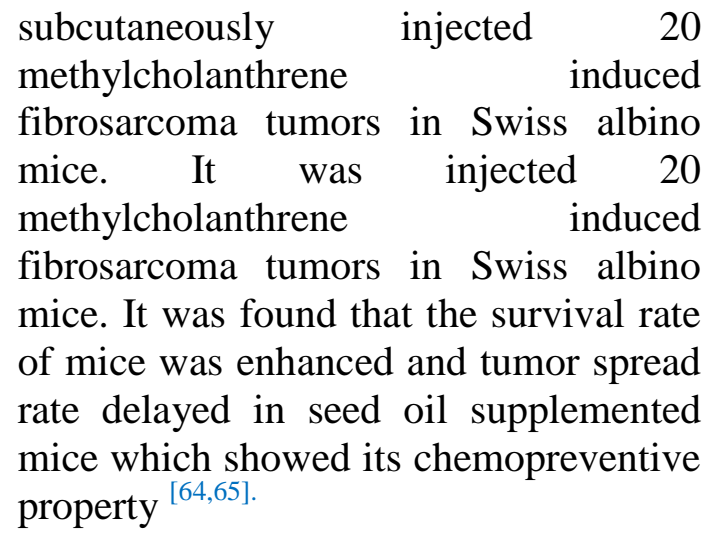

13. Antidepressant and Antianxiety: The ethanolic extract of $O$. sanctum were tested in swiss mice. It was found that the plant extract possesses antidepressant and antianxiety properties and can act as a therapeutic drug against these disorders ${ }^{[66] .}$

14. Antiemetic: It was reported that the leaves of Tulsi possess antiemetic properties and used to treat vomiting diarrhea ${ }^{[67] .}$

15. Anti-fertility: The tulsi leaves were reported to have antifertility property. The experimental study was carried out in albino rats where the model was treated with benzene extract of tulsi leaves for 48 days. Results showed a decrease in sperm count and sperm motility ${ }^{[68,69] \text {. }}$

16. Anti-inflammatory: The presence of fatty acids in the tulsi plant possesses anti-inflammatory activity. The main fatty acid responsible for the antiinflammatory activity is linoleic acid which is capable of blocking the cyclooxygenase and lipoxygenase pathways
$[70]$.

17. Antithyroidic: It was reported that the leaf extract of tulsi leaves acquire antithyroid activity which changes the T3, T4 concentration when tested in male mice ${ }^{[71] \text {. }}$

18. Anti-helminthic: The in-vitro study showed that the eugenol content and essential oil extracted from tulsi leaves possess antihelminthic properties. In the Caenorhabditis model ${ }^{\left[{ }^{p 2]}\right.}$

19. Antihyperlipidemic and Cardioprotective: The reported study has shown that fixed oil of OS decrease high serum lipid concentration and show cardioprotective and antiatherogenic actions against hyperlipidemia when tested in high fat(HF) rat ${ }^{[73] .}$

20. Antifungal: It was studied that the linalool and methyl chavicol content extracted from the essential oil of tulsi leaves showed antifungal property against clinically isolated dermatophytes [74].

\section{CONCLUSION}

Herbal plants are used in Indian for treating and curing various disease because of their high value. Tulsi (Ocimum sanctum) is considered a holy plant. It is mainly used for medicinal purposes and also as an herbal tea. It is used in Ayurveda, Sidha, greek, roman and Unani medicinal systems. It was reported in various research studies that the Ocimum sanctum plant contain therapeutical properties including antiulcer, antistress, antifertility, antiasthmatic, analgesic, antidiabetic, antiinflammatory, antioxidant, antimicrobial and neuroprotective activity. Conclusively from various repeated scientific studies that the Tulsi plant has great medicinal importance and is used worldwide to treat various diseases.

\section{Acknowledgement: None}

\section{Conflict of Interest: None}

\section{Source of Funding: None}

\section{REFERENCES}

1. Medicinal plants have been used for different ailments of human beings all over the world just from the beginning of civilization

2. Kumar V., Andola H.C., Lohani H. and Chauhan N. (2011). Pharmacological Review on Ocimum sanctum Linnaeus: A Queen of herbs. J of Pharm Res, 4:366- 368

3. Atal CK, Kapoor BM. Cultivation and utilization of medicinal plants Eds. PID (SIR). 1989. 
4. Govind P, Madhuri S. Medicinal plants: better remedy for neoplasm. Indian drugs. 2006;43(11):869-74.

5. Singh DK, Hajra PK. Floristic diversity. In Changing Perspective of Biodiversity Status in the Himalaya, GS Gujral, V Sharma, Eds. British Council Division, British High Commission Publication. Wildlife Youth Services: New Delhi, India. 1996, 23-38.

6. Rahal A, Kumar A. Tulsi: A miracle herb in the hands of traditional house lady.

7. Kayastha BL. Queen of herbs tulsi (Ocimum sanctum) removes impurities from water and plays disinfectant role. J Med Plants Stud. 2014;2(2).

8. Kadian R, Parle M. Therapeutic potential and phytopharmacology of tulsi. International Journal of Pharmacy \& Life Sciences. 2012 Jul 1;3(7).

9. McIntosh C. The book of the garden. Roy. 1855.

10. KR K, Basu BD. Ocimum sanctum in Indian Medicinal Plants. Published by LB Basu, Allahabad. 1965.

11. Gupta SK, Prakash J, Srivastava S. Validation of traditional claim of Tulsi, Ocimum sanctum Linn. as a medicinal plant. 2002.

12. Bhamra S, Heinrich M, Howard C, Johnson $\mathrm{M}$, Slater A. DNA authentication of tulsi (Ocimum tenuiflorum) using the nuclear ribosomal internal transcribed spacer (ITS) and the chloroplast intergenic spacer trnHpsbA. Planta Medica. 2015 Nov;81(16):PW_20.

13. Garodia P, Ichikawa H, Malani N, Sethi G, Aggarwal BB. From ancient medicine to modern medicine: ayurvedic concepts of health and their role in inflammation and cancer. J Soc Integr Oncol. 2007 Mar 21;5(1):25-37.

14. Pattanayak P, Behera P, Das D, Panda SK. Ocimum sanctum Linn. A reservoir plant for therapeutic applications: An overview. Pharmacognosy reviews. 2010 Jan;4(7):95.

15. Kadian R, Parle M. Therapeutic potential and phytopharmacology of tulsi. International Journal of Pharmacy \& Life Sciences. 2012 Jul 1;3(7).

16. Sembulingam K, Sembulingam $P$, Namasivayam A. Effect of Ocimum sanctum Linn on noise induced changes in plasma corticosterone level. Indian Journal of Physiology and Pharmacology. 1997 Apr 1;41:139-43.
17. Warrier PK, Nambiar VP, Ramankutty C. Indian medical plants.1995.

18. Kothari SK, Bhattacharya AK, Ramesh S, Garg SN, Khanuja SP. Volatile constituents in oil from different plant parts of methyl eugenol-rich Ocimum tenuiflorum Lf (syn. O. sanctum L.) grown in South India. Journal of Essential Oil Research. 2005 Nov 1;17(6):656-8.

19. Godhwani S, Godhwani JL, Was DS. Ocimum sanctum - a preliminary study evaluating its immunoregulatory profile in albino rats. Journal of Ethnopharmacology. 1988 Dec 1;24(2-3):193-8.

20. Rana L, Tewari G, Pande C. Phytochemical and pharmacological overview on ocimum sanctum linn.: effect of growth stages.

21. Awogbindin IO, Tade OG, Metibemu SD, Olorunsogo OO, Farombi EO. Assessment of flavonoid content, free radical scavenging and hepatoprotective activities of Ocimum gratissimum and Spondias mombin in rats treated with dimethylnitrosamine. Arch Basic Appl Med. 2014 Feb 2;2:45-54.

22. Govaerts R. World Checklist of Lamiaceae., Richmond, London, UK: Royal Botanic Gardens, Kew. 2014.

23. Naji-Tabasi S, Razavi SM. Functional properties and applications of basil seed gum: An overview. Food Hydrocolloids. 2017.

24. Skaltsa H, Tzakou O, Singh M. Note polyphenols of Ocimum sanctum from suriname. Pharmaceutical biology. 1999.

25. Nörr H, Wagner H. New constituents from Ocimum sanctum. Planta medica. 1992.

26. Ahmad A, Rasheed N, Gupta P, Singh S, Siripurapu KB, Ashraf GM, Kumar R, Chand K, Maurya R, Banu N, Al-Sheeha M. Novel Ocimumoside A and B as anti-stress agents: modulation of brain monoamines and antioxidant systems in chronic unpredictable stress model in rats. Phytomedicine. 2012.

27. Kelm MA, Nair MG, Strasburg GM, DeWitt DL. Antioxidant and cyclooxygenase inhibitory phenolic compounds from Ocimum sanctum Linn. Phytomedicine. 2000

28. Grayer RJ, Veitch NC, Kite GC, Price AM, Kokubun T. Distribution of 8-oxygenated leaf-surface flavones in the genus Ocimum. Phytochemistry. 2001.

29. Suzuki A, Shirota O, Mori K, Sekita S, Fuchino H, Takano A, Kuroyanagi M. 
Leishmanicidal active constituents from Nepalese medicinal plant Tulsi (Ocimum sanctum L.). Chemical and Pharmaceutical Bulletin. 2009.

30. Baliga MS, Jimmy R, Thilakchand KR, Sunitha V, Bhat NR, Saldanha E, Rao S, Rao P, Arora R, Palatty PL. Ocimum sanctum L (Holy Basil or Tulsi) and its phytochemicals in the prevention and treatment of cancer. Nutrition and cancer. 2013.

31. Anandjiwala S, Kalola J, Rajani M. Quantification of eugenol, luteolin, ursolic acid, and oleanolic acid in black (Krishna Tulasi) and green (Sri Tulasi) varieties of Ocimum sanctum Linn. using highperformance thin-layer chromatography. Journal of AOAC International. 2006.

32. Singh D, Kumar Chaudhuri P, Darokar MP. New antiproliferative tricyclic sesquiterpenoid from the leaves of Ocimum sanctum. Helvetica Chimica Acta. 2014.

33. Gupta P, Yadav DK, Siripurapu KB, Palit G, Maurya R. Constituents of Ocimum sanctum with antistress activity. Journal of natural products. 2007.

34. Joshi S, Karna AK. Analysis of phytoconstiuents and cytotoxic activities of different parts of Ocimum sanctum. International Journal of Applied Sciences and Biotechnology. 2013.

35. Saharkhiz MJ, Kamyab AA, Kazerani NK, Zomorodian K, Pakshir K, Rahimi MJ. Chemical compositions and antimicrobial activities of Ocimum sanctum L. essential oils at different harvest stages. Jundishapur journal of microbiology. 2015.

36. Kelm MA, Nair MG. Mosquitocidal compounds and a triglyceride, 1, 3dilinoleneoyl-2-palmitin, from Ocimum sanctum. Journal of agricultural and food chemistry. 1998.

37. Kumar A, Gupta G. Pharmacological Effects of Herbal Extracts of Zingiber officinale and Ocimum sanctum Linn. Int. J. Phar. \& Biomedi. Rese. 2020.

38. Suanarunsawat T, Ayutthaya WD, Songsa T, Rattanamahaphoom J. Anti-lipidemic actions of essential oil extracted from Ocimum sanctum L. leaves in rats fed with high cholesterol diet. Journal of Applied Biomedicine. 2009.

39. Sirkar NN. Pharmacological basis of Ayurvedic therapeutics. Cultivation and utilization of medicinal plants. Editors: Atal
CK and Kapoor BM (Published by PID CSIR). 1989.

40. Simon JE, Quinn J, Murray RG. Basil: a source of essential oils. Advances in new crops. 1990:484-9.

41. Meyers M. Basil: an herb society of America guide. The Herb Society of America, Kirtland, Ohio. 2003:6-7.

42. Stella K. The presence of Siva.1992

43. Gupta SM. Plant myths and traditions in India. Brill Archive; 1971.

44. Dyer TF. Thiselton. The folk-lore of plants. New York, Appleton and Co. 1889.

45. Shasany AK. The Holy basil (Ocimum sanctum L.) and its genome. Indian J. Hist. Sci. 2016;51(2):343-50.

46. Prajapati ND, Purohit SS, Sharma AK, Kumar T. A Hand Book of Medicinal Plant, 1st Ed. Agrobios, India: 2003, p. 367.

47. Pandey G, Madhuri S. Pharmacological activities of Ocimum sanctum (tulsi): a review. Int J Pharm Sci Rev Res. 2010 Nov;5(1):61-6.

48. Sharma PV. Dravyagun Vigyan. Chaukambha Bharti Academy, Varanasi, Reprint. 2019

49. Pandey G. Dravyaguna Vijnana. Chowkhamba Krishnadas Academy, Varanasi, Reprint 2004

50. Mudgal D. Dravyagun Vigyan. Ayurvedic Sanskrit Hindi Pustak Bhandar. 2019.

51. Kokate CK, Purohit AP, Gokhale SB. Pharmacognosy, Nirali Prakashan. Page no. 2005.

52. Ansari SH, Islam F, Sameem M. Influence of nanotechnology on herbal drugs: A Review. Journal of advanced pharmaceutical technology \& research. 2012. 65. Basisht GK. Symbiohealth-Need of the hour. Ayu. 2011.

53. Singh S, Majumdar DK. Analgesic activity of Ocimum sanctum and its possible mechanism of action. International journal of Pharmacognosy. 1995.

54. Muralikrishnan G, Pillai SK, Shakeel F. Protective effects of Ocimum sanctum on lipid peroxidation and antioxidant status in streptozocin-induced diabetic rats. Natural product research. 2012.

55. Pandey G, Madhuri S. Pharmacological activities of Ocimum sanctum (tulsi): a review. Int J Pharm Sci Rev Res. 2010.

56. Ghangale GR, Tushar M, Jadhav ND. Evaluation of antiulcer activity of Ocimum sanctum in rats. Veterinary world. 2009. 
57. Singh S, Majumdar DK. Effect of fixed oil of Ocimum sanctum against experimentally induced arthritis and joint edema in laboratory animals. International Journal of Pharmacognosy. 1996.

58. Nadig P, Laxmi S. Study of anti-tussive activity of Ocimum sanctum Linn in guinea pigs. Indian journal of physiology and pharmacology. 2005.

59. Lahon K, Das S. Hepatoprotective activity of Ocimum sanctum alcoholic leaf extract against paracetamol-induced liver damage in Albino rats. Pharmacognosy research. 2011.

60. Jyoti S, Satendra S, Sushma S, Anjana T, Shashi S. Antistressor activity of Ocimum sanctum (Tulsi) against experimentally induced oxidative stress in rabbits. Methods and findings in experimental and clinical pharmacology. 2007.

61. Inbaneson SJ, Sundaram R, Suganthi P. In vitro antiplasmodial effect of ethanolic extracts of traditional medicinal plant Ocimum species against Plasmodium falciparum. Asian Pacific Journal of tropical medicine. 2012.

62. Giridharan VV, Thandavarayan RA, Mani V, Ashok Dundapa T, Watanabe K, Konishi T. Ocimum sanctum Linn. leaf extracts inhibit acetylcholinesterase and improve cognition in rats with experimentally induced dementia. Journal of medicinal food. 2011.

63. Joshi H, Parle M. Cholinergic basis of memory improving effect of Ocimum tenuiflorum Linn. Indian journal of pharmaceutical sciences. 2006.

64. Prakash J, Gupta SK. Chemopreventive activity of Ocimum sanctum seed oil. Journal of ethnopharmacology. 2000.

65. Karthikeyan K, Ravichandran P, Govindasamy S. Chemopreventive effect of Ocimum sanctum on DMBA-induced hamster buccal pouch carcinogenesis. Oral oncology. 1999.

66. Chatterjee M, Verma P, Maurya R, Palit G. Evaluation of ethanol leaf extract of
Ocimum sanctum in experimental models of anxiety and depression. Pharmaceutical biology. 2011.

67. Kumar V, Andola HC, Lohani H, Chauhan $\mathrm{N}$. Pharmacological review on Ocimum sanctum Linnaeus: a queen of herbs. $J$ of Pharm Res. 2011.

68. Ahmed M, Ahamed RN, Aladakatti RH, Ghodesawar MA. Effect of benzene extract of Ocimum sanctum leaves on cauda epididymal spermatozoa of rats. Iranian journal of reproductive medicine. 2011.

69. Sethi J, Yadav M, Sood S, Dahiya K, Singh V. Effect of tulsi (Ocimum Sanctum Linn.) on sperm count and reproductive hormones in male albino rabbits. International journal of Ayurveda research. 2010.

70. Singh S, Majumdar DK. Evaluation of antiinflammatory activity of fatty acids of Ocimum sanctum fixed oil. Indian Journal of Experimental Biology. 1997.

71. Panda S, Kar A. Ocimum Sanctumleaf Extract In The Regulation Of Thyroid Function In The Male Mouse. Pharmacological research. 1998.

72. Asha MK, Prashanth D, Murali B, Padmaja R, Amit A. Anthelmintic activity of essential oil of Ocimum sanctum and eugenol. Fitoterapia. 2001.

73. Khan A, Ahmad A, Akhtar F, Yousuf S, Xess I, Khan LA, Manzoor N. Ocimum sanctum essential oil and its active principles exert their antifungal activity by disrupting ergosterol biosynthesis and membrane integrity. Research in microbiology. 2010.

74. Pandey G, Madhuri S. Pharmacological activities of Ocimum sanctum (tulsi): a review. Int J Pharm Sci Rev Res. 2010.

How to cite this article: Thakur S, Choudhary S, Walia B et.al. Tulsi - a review based upon its ayurvedic and modern therapeutic uses. International Journal of Research and Review. 2021; 8(5): 263-272. DOI: https://doi.org/10. 52403/ijrr.20210534 